\title{
An Efficient and Short Route for the Synthesis of Reverse Pyrrole Ribonucleosides
}

\author{
Letícia O. R. Pereira ${ }^{a}$, Anna C. Cunha ${ }^{b}$, Maria Cecília B. V. de Souza ${ }^{a}$ and Vitor F. Ferreira ${ }^{* a}$ \\ ${ }^{a}$ Departamento de Química Orgânica, Instituto de Química,Universidade Federal Fluminense, \\ Outeiro de São João Batista, s/n, 24210-150, Niterói - RJ, Brazil
}

${ }^{b}$ Núcleo de Pesquisa de Produtos Naturais, Universidade Federal do Rio de Janeiro, 21941-970, Rio de Janeiro RJ, Brazil

\begin{abstract}
Neste trabalho estão descritas as sínteses dos ribonucleosídeos pirrólicos reversos 5-C-(4acetil-5-metil-pirrol-1-il)-2,3-O-isopropilideno-5-desoxi- $\beta$-D-ribofuranosídeo de metila (10), 5-C(4-etoxicarbonil-5-metil-pirrol-1-il)-2,3-O-isopropilideno-5-desoxi- $\beta$-D-ribofuranosídeo de metila (11), 5-C-(4-acetil-5-metil-pirrol-1-il)-5-desoxi- $\beta$-D-ribofuranosídeo de metila (12), 5-C-(4etoxicarbonil-5-metil-pirrol-1-il)-5-desoxi- $\beta$-D-ribofuranosídeo de metila (13), 5-desoxi-5-C-(3'formil-4'-hidroxipropil-pirrol-1'-il)-2,3-O-isopropilideno- $\beta$-D-ribofuranosídeo de metila (16) e 5desoxi-5-C-(3'-formil-pirrol-1'-il)-2,3-O-isopropilideno- $\beta$-D-ribofuranosídeo de metila (18) a partir do 5-amino-5-desoxi-2,3-O-isopropilideno- $\beta$-D-ribofuranosídeo de metila (9), matéria-prima de fácil preparação. A estratégia sintética para a construção do anel heterocíclico baseou-se no ataque nucleofílico da amina 9 aos diidrofuranos: 4-acetil-2-n-butoxi-5-metil-4,5-diidrofurano (4), 4carbetoxi-2-n-butoxi-5-metil-4,5-diidrofurano (5), 4-formil-2- $n$-butoxi-4,5-diidrofurano (6) e 4formil-1-metil dioxabiciclo[3.3.0]oct-3-eno (8, in situ), obtidos através da reação dos diazo compostos 3-diazo-2,4-pentadiona (1), 2-diazoacetoacetato de etila (2) e diazomalonaldeído (3) com enoléteres, sob catálise de tetraacetato de di-ródio.
\end{abstract}

The synthesis of reverse pyrrole ribonucleosides methyl 5-C-(4-acetyl-5-methyl-pyrrol-1-yl)2,3-O-isopropylidene-5-deoxy- $\beta$-D-ribofuranoside (10), methyl 5-C-(4-ethoxycarbonyl-5-methylpyrrol-1-yl)-2,3-O-isopropylidene-5-deoxy- $\beta$-D-ribofuranoside (11), methyl 5-C-(4-acetyl-5-methylpyrrol-1-yl)-5-deoxy- $\beta$-D-ribofuranoside (12), methyl 5-C-(4-ethoxycarbonyl-5-methyl-pyrrol-1yl)-5-deoxy- $\beta$-D-ribofuranoside (13), methyl 5-deoxy-5-C-(3'-formyl-4'-hydroxypropyl-pyrrol1'-yl)-2,3-O-isopropylidene- $\beta$-D-ribofuranoside (16) and methyl 5-deoxy-5-C-(3'-formyl-pyrrol1'-yl)-2,3-O-isopropylidene- $\beta$-D-ribofuranoside (18) are described starting from readily available methyl 5-amino-5-deoxy-2,3-O-isopropylidene- $\beta$-D-ribofuranoside (9). The synthetic strategy for the construction of the heterocyclic ring was based on the nucleophilic attack of $(9)$ to 4 -acetyl-2-nbutoxy-5-methyl-4,5-dihydrofuran (4), 4-carbetoxy-2-n-butoxy-5-methyl-4,5-dihydrofuran (5), 4formyl-2- $n$-butoxy-4,5-dihydrofuran (6) and 4-formyl-1-methyl dioxabyciclo[3.3.0]oct-3-en (8, in situ). The later compounds were obtained from reaction between 3-diazo-2,4-pentadione (1), ethyl 2-diazoacetoacetate (2) or diazomalonaldehyde (3) and enol ethers using dirhodium tetraacetate as a catalyst.

Keywords: pyrrole nucleosides, reverse nucleosides, diazo, pyrrole

\section{Introduction}

The pyrrole unit occurs in many interesting classes of compounds such as polymers, ${ }^{1}$ molecular electronics ${ }^{2}$ and as building blocks in important natural products, such as heme, chlorophyll, bile pigments, and vitamin $\mathrm{B}_{12}$. It is also present, for example, in the structure of alkaloids from marine polysources, ${ }^{3} \mathrm{~N}$-bridged pyrroles and pyrrolizidine

\footnotetext{
*e-mail: cegvito@vm.uff.br
}

and indolizidine alkaloids. ${ }^{4}$ A large variety of polyhalogenated pyrroles isolated from natural sources showed pronounced physiological activities. ${ }^{5} \mathrm{~A}$ series of synthetic 1,2-diarylpyrroles were found to be potent and selective inhibitors of the human cyclooxygenase-2 (COX2) enzyme. ${ }^{6}$ Recently, some 1-phenyl-3-(aminomethyl) pyrroles prepared from aniline showed high affinities for D2, D3, and D4 dopamine receptor subtypes. ${ }^{\text {? }}$

The syntheses of pyrrole heterocycles have been featured in a number of review articles and books. ${ }^{89}$ The 
classical methods for the preparation of pyrroles include the Knorr synthesis, the Paal-Knorr synthesis, the Hantzsch synthesis, and cycloaddition reactions between nitrile ylides and alkynes. ${ }^{10}$ Although these synthetic approaches are broad, more versatile, selective and efficient methods are still desirable.

In the area of nucleosides, only few methods are suitable for preparing pyrrole nucleoside derivatives. ${ }^{11}$ The development of synthetic methods that allow access to nucleoside analogs having modifications in both the sugar and heterocycle moieties is decidedly important and have been extensively studied. For example, 2',3'-dideoxyribonucleosides such as 3'-azido-3'-deoxythymidine (AZT), 2', 3'-dideoxyinosine (DDI), 2', 3'-dideoxycytidine (DDC) and $\beta$-L-(-)-2'-deoxy-3'-thiacytidine (Lamivudine ${ }^{\circledR}$, 3TC) are potent antivirals being effective against human immunodeficiency virus (HIV). ${ }^{12}$ Ganciclovir $^{\circledast}$, Foscarnet ${ }^{\circledR}$ and Cidofovir $^{\otimes}$ are drugs available for treatment of human cytomegalovirus (HCMV). ${ }^{13}$ Oxetanocins A and B are carbocyclic nucleosides that show potent antiviral, antitumor, and antibacterial activities, including activity against $\mathrm{HCMV}^{14}$

As part of an ongoing research program on the synthesis of new nucleoside compounds ${ }^{15}$ and on the basis of our experience in the field of the use of a-diazocarbonyl compounds ${ }^{16}$ in organic synthesis, we report herein an efficient and short route for the synthesis of reverse pyrrole ribonucleosides employing a methodology that consists in the construction of the heterocyclic ring starting from methyl 5-amino-5-deoxy-2,3- $O$-isopropylidene- $\beta$-Dribofuranoside (9), a readily available starting material.

\section{Experimental}

\section{General procedures}

Melting points were determined on a Fisher-Johns apparatus and are uncorrected. Analytical grade solvents were used. Dry tetrahydrofuran was freshly distilled from sodium and benzophenone before being used. Chromatography column was performed on silica gel 60 (Merck 70-230 mesh). Infrared spectra were recorded on a Perkin-Elmer 1420 spectrophotometer. NMR spectra were recorded with a Varian Unity Plus 300 spectrometer, operating at $300 \mathrm{MHz}\left({ }^{1} \mathrm{H}\right)$ and $75 \mathrm{MHz}\left({ }^{13} \mathrm{C}\right)$, with tetramethylsilane as the internal standard. Low-resolution electron-impact mass spectra $(12 \mathrm{eV}$ and 70 eV) were obtained using a Hewlett Packard 5985 instrument. High-resolution electron-impact mass spectra $(70 \mathrm{eV})$ were obtained using VG Auto Spec instrument and high-resolution fast atom bombardment mass spectra (HRFABMS) were recorded in a 3-NBA (3-nitrobenzyl alcohol) matrix in the positive ion mode on a VGZAB-E mass spectrometer. 3-Diazo2,4-pentadione (1), ${ }^{17}$ 3-diazoethyl acetoacetate (2), ${ }^{18}$ diazomalonaldehyde (3) ${ }^{19}$ and aminofuranoside (9) were prepared following the procedures described in the literature. The dihydrofurans $\mathbf{4}$ and $\mathbf{5}$ had their preparation reported recently. ${ }^{20}$ Purified samples were used for measuring physical constants and spectral data.

Methyl 5-C-(3-acetyl-2-methyl-pyrrol-1-yl)-2,3-Oisopropylidene-5-deoxy- $\beta$-D-ribofuranoside (10): method A

A solution of amine $9(217 \mathrm{mg}, 1.07 \mathrm{mmol})$ in $1 \mathrm{~cm}^{3}$ of methanol and $0.3 \mathrm{~cm}^{3}$ of acetic acid was added dropwise to a stirred solution of $4(602 \mathrm{mg}, 3.04 \mathrm{mmol})$ in $5 \mathrm{~cm}^{3}$ of methanol. The stirring was continued for 24 hours at $80^{\circ} \mathrm{C}$ and then the solution was evaporated under reduced pressure yielding an oil, which was purified by column chromatography on silica gel (7:3n-hexane-ethyl acetate). Pyrrole 10 (228 mg, 69 \%) was obtained as colorless oil. ${ }^{1} \mathrm{H} \mathrm{NMR}\left(300 \mathrm{MHz}, \mathrm{CDCl}_{3}\right) \delta 1.30(3 \mathrm{H}, \mathrm{s}, \mathrm{H} 7$ ') $1.46(3 \mathrm{H}$, s, H8'), $2.40\left(3 \mathrm{H}, \mathrm{s}, \mathrm{CH}_{3} \mathrm{C}=\mathrm{O}\right), 2.70\left(3 \mathrm{H}, \mathrm{s}, \mathrm{CH}_{3}-\mathrm{C}_{2}\right), 3.39$ $\left(3 \mathrm{H}, \mathrm{s}, \mathrm{OCH}_{3}\right), 3.97(2 \mathrm{H}, \mathrm{d}, J 7.5 \mathrm{~Hz}, \mathrm{H} 5$ '), $4.42(1 \mathrm{H}, \mathrm{td}, J 7.5$ and $0.9 \mathrm{~Hz}, \mathrm{H} 4$ '), $4.61(1 \mathrm{H}, \mathrm{dd}, J 6.0$ and $0.9 \mathrm{~Hz}, \mathrm{H} 3$ '), 4.67 $(1 \mathrm{H}, \mathrm{d}, J 6.0 \mathrm{~Hz}, \mathrm{H} 2$ '), 5.00 (1H, s, H1'), 6.51 (1H, d, J 3.0 $\mathrm{Hz}, \mathrm{H} 4), 6.57(1 \mathrm{H}, \mathrm{d}, J 3.0 \mathrm{~Hz}, \mathrm{H} 5) ;{ }^{13} \mathrm{C}$ NMR $(75 \mathrm{MHz}$, $\left.\mathrm{CDCl}_{3}\right) \delta 11.4\left(\mathrm{CH}_{3} \mathrm{C}_{2}\right) 24.8\left(\mathrm{C}^{\prime}\right.$ '), $26.3\left(\mathrm{C}^{\prime}\right), 28.3$ $\left(\mathrm{CH}_{3} \mathrm{C}=\mathrm{O}\right), 49.1\left(\mathrm{C}-5^{\prime}\right), 55.4\left(\mathrm{OCH}_{3}\right), 81.6\left(\mathrm{C}-3^{\prime}\right), 84.9(\mathrm{C}-$ 2'), 85.3 (C-4'), 109.9 (C-1'), 110.3 (C-4), 112.7 (C-6'), 119.8 (C-5), 121.5 (C-3), $134.7(\mathrm{C}-2), 194.9(\mathrm{C}=\mathrm{O})$; LREIMS $m / z$ (relative abundance \%) $154(12), 309\left(\mathrm{M}^{+}\right.$, 100); HRFABMS Found for $(\mathrm{M}+\mathrm{H})^{+}: 310.1702$. Calcd for $(\mathrm{M}+\mathrm{H}) \mathrm{C}_{16} \mathrm{H}_{24} \mathrm{O}_{5} \mathrm{~N}: 310.1654$.

Methyl 5-C-(3-ethoxycarbonyl-2-methyl-pyrrol-1-yl)-2,3$O$-isopropylidene-5-deoxy- $\beta$-D-ribofuranoside (11): method $B$

A solution of 5 (702 $\mathrm{mg}, 3.08 \mathrm{mmol})$, the amine $9(227$ $\mathrm{mg}, 1.12 \mathrm{mmol}$ ) and $0.3 \mathrm{~cm}^{3}$ of acetic acid in $5.0 \mathrm{~cm}^{3}$ of isopropyl alcohol/water $(2: 1)$ was stirred at $100{ }^{\circ} \mathrm{C}$ for 24 hours. Afterwards, the solution was evaporated under reduced pressure and the resultant oil was purified by column chromatography on silica gel (9:1 $n$-hexane-ethyl acetate) giving a pale yellow solid (243 mg, $64 \%)$ : mp 64-66 ${ }^{\circ} \mathrm{C}$; IR $v_{\text {max }} / \mathrm{cm}^{-1} 1698,1554,1390,1253(\mathrm{KBr}) ;{ }^{1} \mathrm{H}$ NMR (300 MHz, $\left.\mathrm{CDCl}_{3}\right) \delta 1.29\left(3 \mathrm{H}, \mathrm{s}, \mathrm{H} 7^{\prime}\right), 1.33(3 \mathrm{H}, \mathrm{t}, J$ $\left.7.2 \mathrm{~Hz}, \mathrm{OCH}_{2} \mathrm{CH}_{3}\right) 1.46\left(3 \mathrm{H}, \mathrm{s}, \mathrm{H} 8\right.$ '), $3.39\left(3 \mathrm{H}, \mathrm{s}, \mathrm{OCH}_{3}\right)$, $3.96(2 \mathrm{H}, \mathrm{dd}, J 6.9$ and $1.5 \mathrm{~Hz}, \mathrm{H} 5$ '), $4.25(2 \mathrm{H}, \mathrm{q}, J 7.2 \mathrm{~Hz}$, $\left.\mathrm{OC}_{2} \mathrm{CH}_{3}\right), 2.54\left(3 \mathrm{H}, \mathrm{s}, \mathrm{CH}_{3} \mathrm{C}_{2}\right), 4.41(1 \mathrm{H}, \mathrm{td}, J 6.9$ and 0.9 $\mathrm{Hz}, \mathrm{H}^{\prime}$ '), 4.60 (1H, dd, J 5.8 and $0.9 \mathrm{~Hz}, \mathrm{H} 3$ '), $4.66(1 \mathrm{H}, \mathrm{d}$, 
$J 5.7 \mathrm{~Hz}, \mathrm{H} 2$ ') $, 5.00(1 \mathrm{H}, \mathrm{s}, \mathrm{H} 1$ ') $), 6.55(1 \mathrm{H}, \mathrm{d}, J 3.3 \mathrm{~Hz}, \mathrm{H} 4)$, $6.56(1 \mathrm{H}, \mathrm{d}, J 3.0 \mathrm{~Hz}, \mathrm{H} 5) ;{ }^{13} \mathrm{C}$ NMR $\left(75 \mathrm{MHz}, \mathrm{CDCl}_{3}\right) \delta$ $11.0\left(\mathrm{CH}_{3} \mathrm{C}_{2}\right), 14.4\left(\mathrm{OCH}_{2} \mathrm{CH}_{3}\right), 24.7$ (C-7'), $26.2\left(\mathrm{C}^{-} 8^{\prime}\right)$, $49.3\left(\mathrm{C}-5\right.$ '), $55.3\left(\mathrm{OCH}_{3}\right), 59.1\left(\mathrm{OCH}_{2} \mathrm{CH}_{3}\right), 81.5(\mathrm{C}-3$ ') 84.9 (C-2'), 85.2 (C-4'), 109.7 or 109.8 (C-1'), 109.7 or 109.8 (C-4), 112.6 (C-6'), 119.9 (C-5), 135.1 (C-2), 165.3 $(\mathrm{C}=\mathrm{O}),(\mathrm{C} 3$, the signal for this car was not observed $)$; LREIMS $m / z$ (relative abundance \%) $m / z 339\left(\mathrm{M}^{+*}, 100\right)$, 308 (87), 294 (80); HRFABMS Found: 339.1745. Calcd for $\mathrm{C}_{17} \mathrm{H}_{25} \mathrm{NO}_{6}(\mathrm{M})^{+}: 339.1681$.

General procedure for removing the acetal group of $\mathbf{1 0}$ and 11

A solution of the corresponding nucleoside $\mathbf{1 0}$ or $\mathbf{1 1}$ $(0.26-0.31 \mathrm{mmol})$ in $3.0 \mathrm{~cm}^{3}$ of iodine-methanol solution $(1 \% \mathrm{w} / \mathrm{V})$ was stirred at $70{ }^{\circ} \mathrm{C}$ for 10 hours. Afterwards, drops of aqueous potassium thiosulfate solution $(0,5 \mathrm{~N})$ were added to the reaction mixture, which was then evaporated under reduced pressure. The residue was purified by chromatography column on silica gel ( $2: 8$ hexane:ethyl acetate) giving the pyrroles $\mathbf{1 2}$ and $\mathbf{1 3}$.

Methyl 5-C-(3-acetyl-2-methyl-pyrrol-1-yl)-5-deoxy- $\beta$-Dribofuranoside (12)

Nucleoside 10 (88 mg, $0.31 \mathrm{mmol})$ led to $\mathbf{1 2}(58 \mathrm{mg}$, $70 \%$ ) as a white solid: $\mathrm{mp} 138-140{ }^{\circ} \mathrm{C}$; IR $v_{\max } / \mathrm{cm}^{-1}: 3486$, 1651, $1634(\mathrm{KBr}) ;{ }^{1} \mathrm{H}$ NMR (300 MHz, DMSO-d $) \delta 2.4$ $\left(3 \mathrm{H}, \mathrm{s}, \mathrm{CH}_{3} \mathrm{C}=\mathrm{O}\right), 2.60\left(3 \mathrm{H}, \mathrm{s}, \mathrm{CH}_{3} \mathrm{C}_{2}\right), 3.30\left(3 \mathrm{H}, \mathrm{s}, \mathrm{OCH}_{3}\right)$, $3.82(1 \mathrm{H}, \mathrm{d}, J 7.5 \mathrm{~Hz}, \mathrm{H} 2$ '), 3.90 (1 $1 \mathrm{H}$, ddd, $J 7.4 ; 6.6$ and 4.5 Hz, H3'), 3.97 (1H, dd, J 14.1 and 2.4 Hz, H5'), $4.06(1 \mathrm{H}$, td, $J 7.4$ and $\left.2.4 \mathrm{~Hz}, \mathrm{H} 4^{\prime}\right), 4.27(1 \mathrm{H}, \mathrm{dd}, J 14.2$ and $7.2 \mathrm{~Hz}$, H5”), 4.73 (1H, s, H1'), 5.22 (1H, d, J 6.6 Hz, C2'-OH), 5.31 $(1 \mathrm{H}, \mathrm{d}, J 4.2 \mathrm{~Hz}, \mathrm{C} 3$ '-OH), 6.59 (1H, d, J3.0 Hz, H4), 6.79 $(1 \mathrm{H}, \mathrm{d}, J 3.0 \mathrm{~Hz}, \mathrm{H} 5) ;{ }^{13} \mathrm{C}$ NMR $\left(75.0 \mathrm{MHz}\right.$, DMSO-d $\left.{ }_{6}\right) \delta$ $11.2\left(\mathrm{CH}_{3} \mathrm{C}_{2}\right), 28.5\left(\mathrm{CH}_{3} \mathrm{C}=\mathrm{O}\right), 49.1(\mathrm{C}-5), 54.8\left(\mathrm{OCH}_{3}\right)$, 71.9 (C-3'), 74.1 (C-2'), 81.1 (C-4'), 108.5 (C-1'), 109.6 (C-4), $120.6(\mathrm{C}-3), 121.2(\mathrm{C}-5), 134.5(\mathrm{C}-2), 193.7(\mathrm{C}=\mathrm{O})$; LREIMS $m / z$ (relative abundance \%) $270\left(\mathrm{M}^{+*}, 48\right), 154$ (100), 136 (51); HRFABMS Found: 270.1331. Calcd for $\mathrm{C}_{13} \mathrm{H}_{20} \mathrm{NO}_{5}(\mathrm{M}+\mathrm{H})^{+}: 270.1341$.

Methyl 5-C-(3-ethoxycarbonyl-2-methyl-pyrrol-1-yl)-5deoxy- $\beta$-D-ribofuranoside (13)

Nucleoside 11 ( $88 \mathrm{mg}, 0.26 \mathrm{mmol})$ led to $13(51 \mathrm{mg}$, $66 \%$ ) as a white solid: $\mathrm{mp} 109-110{ }^{\circ} \mathrm{C}$; IR $v_{\max } / \mathrm{cm}^{-1} 3353$, $1698(\mathrm{KBr}) ;{ }^{1} \mathrm{H}$ NMR $\left(300 \mathrm{MHz}, \mathrm{DMSO}-\mathrm{d}_{6}\right) \delta 1.35(3 \mathrm{H}, \mathrm{t}$, $\left.J 7.2 \mathrm{~Hz}, \mathrm{OCH}_{2} \underline{\mathrm{C}}_{3}\right), 2.60\left(3 \mathrm{H}, \mathrm{s}, \mathrm{C}_{3} \mathrm{C}_{2}\right), 3.34\left(3 \mathrm{H}, \mathrm{s}, \mathrm{OC}_{3}\right)$, $3.82(2 \mathrm{H}, \mathrm{d}, J 4.2 \mathrm{~Hz}, \mathrm{H} 2$ '), $3.89(1 \mathrm{H}, \mathrm{dd}, J 7.5$ and $4.5 \mathrm{~Hz}$,
H3'), 3.98 (1H, dd, $J 14.1$ e 7.5 Hz, H5'), 4.06 (1H, td, $J 7.2$ and $2.4 \mathrm{~Hz}, \mathrm{H} 4$ '), $4.26\left(2 \mathrm{H}, \mathrm{q}, J 7.2 \mathrm{~Hz}, \mathrm{OCH}_{2} \mathrm{CH}_{3}\right), 4.25$ $(1 \mathrm{H}, \mathrm{dd}, J 14.1$ and $2.4 \mathrm{~Hz}, \mathrm{H} 5$ "), $4.73(1 \mathrm{H}, \mathrm{s}, \mathrm{H} 1$ '), 5.24 (2H, broad singlet, C2'-OH and C3'-OH), $6.45(1 \mathrm{H}, \mathrm{d}, J 3.0$ $\mathrm{Hz}, \mathrm{H} 4), 6.79(1 \mathrm{H}, \mathrm{d}, J 3.0 \mathrm{~Hz}, \mathrm{H} 5) ;{ }^{13} \mathrm{C}$ NMR $(75 \mathrm{MHz}$, DMSO-d $\mathrm{d}_{6} \delta 11.2\left(\mathrm{CH}_{3} \mathrm{C}_{2}\right), d 14.1\left(\mathrm{OCH}_{2} \mathrm{CH}_{3}\right), 49.3\left(\mathrm{C}-5^{\prime}\right)$, 54,9 $\left(\mathrm{OCH}_{3}\right), 58.7\left(\mathrm{OCH}_{2} \mathrm{CH}_{3}\right), 71.9\left(\mathrm{C}-3^{\prime}\right), 74.1\left(\mathrm{C}-2^{\prime}\right)$, 81.1 (C-4'), 108.6 or 108.7 (C-1'), 108.6 or 109.7 (C-4), $111.2(\mathrm{C}-3), 121.4(\mathrm{C}-5), 135.5(\mathrm{C}-2), 164.7(\mathrm{C}=\mathrm{O})$; LREIMS $m / z$ (relative abundance \%) $299\left(\mathrm{M}^{+}, 38\right), 154$ (100), 136 (74); HRFABMS Found: 299.1347. Calcd for $\mathrm{C}_{14} \mathrm{H}_{21} \mathrm{NO}_{6}(\mathrm{M})^{+} 299.1368$.

\section{General procedure for obtaining 14, 15 and 17}

A solution of diazomalonaldehyde (3) in $10.0 \mathrm{~cm}^{3}$ of freshly distilled vinyl ether was slowly added at a rate of $1.0 \mathrm{~cm}^{3} / \mathrm{h}$ (syringe pump) to a stirred suspension of dirhodium tetraacetate $(0.03 \mathrm{mmol})$ in $15.0 \mathrm{~cm}^{3}$ of the same vinyl ether as solvent, under nitrogen atmosphere, at room temperature. Stirring was carried on for 24 hours or more. The organic mixture was concentrated under reduced pressure followed by the addition of $10.0 \mathrm{~cm}^{3}$ of methanol, the appropriate amine and $0.2 \mathrm{~cm}^{3}$ of glacial acetic acid. The mixture was stirred for 24 hours. Afterwards, the mixture was acidified with $2 \mathrm{M}$ hydrochloric acid and extracted with ethyl acetate $\left(3 \times 10.0 \mathrm{~cm}^{3}\right)$. The combined organic phases were washed with aqueous sodium bicarbonate solution and dried over anhydrous magnesium sulfate. The solvent was removed under reduced pressure and the residue was purified by chromatography column on silica gel, using $n$-hexane:chloroform (1:1) or chloroform:acetone (9:1) as eluents.

\section{2-[4'-(1'-Benzyl-3'-formyl-5'-methyl)pyrrol-1'-yl]ethanol} (14)

The reaction using 3 (157 $\mathrm{mg}, 1.60 \mathrm{mmol})$, benzylamine (981 mg, $9.00 \mathrm{mmol}$ ) and 4,5-dihydro-2-methyl-furan led to $14(196 \mathrm{mg}, 50 \%)$ as a pale yellow oil; IR $v_{\text {max }} / \mathrm{cm}^{-1} 3400$ (O-H), 1720 (C=O of aldehyde) (neat); ${ }^{1} \mathrm{H}$ NMR $(300 \mathrm{MHz}$, $\left.\mathrm{CDCl}_{3}\right) \delta 2.08\left(3 \mathrm{H}, \mathrm{s}, \mathrm{CH}_{3}-\mathrm{C} 5\right.$ '), $2.96(2 \mathrm{H}, \mathrm{t}, J 6.0 \mathrm{~Hz}, \mathrm{H} 2)$, $3.80(2 \mathrm{H}, \mathrm{t}, J 6.0 \mathrm{~Hz}, \mathrm{H} 1), 5.06(2 \mathrm{H}, \mathrm{s}, \mathrm{H6}$ ') , 7.08-7.05 (2H, m, H2" and H6"), $7.22(1 \mathrm{H}, \mathrm{s}, \mathrm{H} 2), 7.35-7.32$ (2H, m, H3"and H5"), 7.40-7.37 (1H, m, H4"), 9.68 (1H, s, CHO), (OH signal was not observed); ${ }^{13} \mathrm{C} \mathrm{NMR}\left(75 \mathrm{MHz}, \mathrm{CDCl}_{3}\right) \delta 9.2(\mathrm{CH} 3-$ C5'), 29.6 (C2), 51.3 (C6'), 63.7 (C1), 117.5 (C5'), 124.1 (C4'), 126.6 (C2"and C6"), 128.0 (C3" and C5"), 128.9 (C4”), 129.8 (C3'), 132.1 (C2'), 135.9 (C1"), 186.2 (ㄷHO); LREIMS $m / z$ (relative abundance \%) $243\left(\mathrm{M}^{+}, 5\right), 212(10)$, 197 (4), 91 (100), 65 (8). 


\section{3-[4'-(l'-Benzyl-3'-formyl)-pyrrol-1'-yl]-1-propanol (15)}

The reaction of 3 (157 mg, $1.60 \mathrm{mmol})$, benzylamine (981 mg, $9.00 \mathrm{mmol}$ ) and 3,4-dihydro-2H-pyran led to $\mathbf{1 5}$ (205 mg, 53\%) as a pale yellow oil; IR $v_{\max } / \mathrm{cm}^{-1} 3020$ $3050(\mathrm{O}-\mathrm{H}), 1650\left(\mathrm{C}=\mathrm{O}\right.$ of aldehyde) (neat); ${ }^{1} \mathrm{H}$ NMR (300 $\left.\mathrm{MHz}, \mathrm{CDCl}_{3}\right) \delta 1.81\left(2 \mathrm{H}, \mathrm{tt}, J 6.0\right.$ and $\left.6.9 \mathrm{~Hz}, \mathrm{H} 2_{\text {side chain }}\right)$, $2.82(2 \mathrm{H}, \mathrm{t}, J 6.9 \mathrm{~Hz}, \mathrm{H} 3), 3.61(2 \mathrm{H}, \mathrm{t}, J 6.0 \mathrm{~Hz}, \mathrm{H} 1), 5.04$ ( $2 \mathrm{H}, \mathrm{s}, \mathrm{H6}$ '), $6.50(1 \mathrm{H}, \mathrm{dd}, J 0.6$ and $2.1 \mathrm{~Hz}, \mathrm{H} 5$ '), $7.15-7.20$ $\left(2 \mathrm{H}, \mathrm{m}, \mathrm{H} 2\right.$ " and $\left.\mathrm{H} 6{ }_{\mathrm{Ar}}\right), 7.22(1 \mathrm{H}, \mathrm{d}, J 2.1 \mathrm{~Hz}, \mathrm{H} 2), 7.32-$ 7.35 (2H, m, H3" and H5"), 7.36-7.40 (1H, m, H4'), 9.72 $(1 \mathrm{H}, \mathrm{d}, J 0.6, \mathrm{CHO}),\left(\mathrm{OH}\right.$ signal was not observed); ${ }^{13} \mathrm{C}$ NMR (75 MHz, $\left.\mathrm{CDCl}_{3}\right) \delta 21.2(\mathrm{C} 3), 33.5(\mathrm{C} 2), 53.6$ (C6'), 61.1 (C1), 121.8 (C5'), 124.4 (C4'), 125.1 (C3'), 127.2 (C2" and C6"), 128.1 (C3" and C5"), 128.8 (C4"), 131.6 (C2'), 135.8 (C1"), 185.9 ( $\mathrm{CHO}$ ); LREIMS m/z (relative abundance \%) $243\left(\mathrm{M}^{+*}, 45\right), 244$ (5), 225 (8), 199 (35), $170(3), 91$ (100), 65 (8).

\section{1-Benzyl-3-formyl-pyrrol-1-yl (17)}

The reaction of 3 (206 mg, $2.1 \mathrm{mmol})$, benzylamine (981 mg, $9.00 \mathrm{mmol}$ ) and $n$-butyl vinyl ether led to 17 (60 $\mathrm{mg}, 16 \%)$ as a pale yellow oil; IR $v_{\max } / \mathrm{cm}^{-1} 1660(\mathrm{C}=\mathrm{O}$, aldehyde) (neat); ${ }^{1} \mathrm{H}$ NMR $\left(300 \mathrm{MHz}, \mathrm{CDCl}_{3}\right) \delta 5.10(2 \mathrm{H}$, $\mathrm{s}, \mathrm{H} 6), 6.66(1 \mathrm{H}, \mathrm{dd}, J 1.8$ and $2.4 \mathrm{~Hz}, \mathrm{H} 4), 6.71(1 \mathrm{H}, \mathrm{t}, J 2.4$ Hz, H5), 7.15-7.20 (2H, m, H2' and H6'), 7.31 (1H, t, J 1.8 $\mathrm{Hz}, \mathrm{H} 2)$, 7.33-7.36 (2H, m, H3' and H5'), 7.37-7.42 (1H, m, $\mathrm{H} 4$ '), $9.74(1 \mathrm{H}, \mathrm{s}, \mathrm{CHO}) ;{ }^{13} \mathrm{C} \mathrm{NMR}\left(75 \mathrm{MHz}, \mathrm{CDCl}_{3}\right) \delta 53.8$ (C6), 108.5 (C4), 123.6 (C5), 126.7 (C3), 127.2 (C2' and C6'), 128.1 (C3' and C5'), 128.8 (C4'), 129.0 (C2), 136.0 (C1'), 185.2 (CHO); LREIMS $m / z$ (relative abundance \%) $185\left(\mathrm{M}^{+}, 47\right), 156$ (4), 91 (100), 65 (25); HREIMS Found: 185.0841. Calcd for $\mathrm{C}_{12} \mathrm{H}_{11} \mathrm{NO}(\mathrm{M})^{+\bullet} 185.0840$.

\section{General procedure for obtaining 16 and 18}

A solution of diazomalonaldehyde (3) in $10.0 \mathrm{~cm}^{3}$ of freshly distilled vinyl ether was slowly added at a rate of $1.0 \mathrm{~cm}^{3} / \mathrm{h}$ (syringe pump) to a stirred suspension of dirhodium tetraacetate $(0.03 \mathrm{mmol})$ in $15.0 \mathrm{~cm}^{3}$ of the same vinyl ether as solvent, under nitrogen atmosphere. Stirring was carried on for 24 hours or more. The organic mixture was concentrated under reduced pressure, the catalyst was removed by chromatography column on Florisi ${ }^{\circledR}$ using $n$ hexane:chloroform (1:1) as eluent. The organic mixture was concentrated under reduced pressure, followed by the addition of $10.0 \mathrm{~cm}^{3}$ of methanol, the appropriate amine and $0.2 \mathrm{~cm}^{3}$ of glacial acetic acid. The mixture was stirred for 48 hours. The solvent was removed under reduced pressure and the residue was purified by chromatography column on silica gel, using $n$-hexane:chloroform (1:1) or chloroform: acetone (9:1) as the eluent.

Methyl 5-deoxy-5-C-(3'-formyl-4'-hydroxypropyl-pyrrol1 '-yl)-2,3-O-isopropylidene- $\beta$-D-ribofuranoside (16)

The reaction of $\mathbf{3}(196 \mathrm{mg}, 2.00 \mathrm{mmol})$, amine-riboside 9 (107 mg , $0.50 \mathrm{mmol}$,) and 3,4-dihydro-2H-pyran led to 16 (67 mg, 37\%) as an oil; IR $v_{\text {max }} / \mathrm{cm}^{-1} 3360(\mathrm{O}-\mathrm{H}), 1660$ (C=O, aldehyde), 1370-1380 (geminal methyl) (neat); ${ }^{1} \mathrm{H}$ NMR (300 MHz, $\left.\mathrm{CDCl}_{3}\right) \delta 1.32(3 \mathrm{H}, \mathrm{s}, \mathrm{H} 7), 1.48(3 \mathrm{H}, \mathrm{s}$, $\mathrm{H} 8), 1.82(2 \mathrm{H}, \mathrm{tt}, J 7.2$ and $6.0 \mathrm{~Hz}, \mathrm{H} 2$ "), $2.83(2 \mathrm{H}, \mathrm{t}, J 7.2$ $\mathrm{Hz}, \mathrm{H} 3$ "), 3.40 (3H, s, $\left.\mathrm{OCH}_{3}\right), 3.62$ (2H, t, J $6.0 \mathrm{~Hz}, \mathrm{H1}$ "), $4.00(2 \mathrm{H}, \mathrm{d}, J 7.8 \mathrm{~Hz}, \mathrm{H} 5), 4.47(1 \mathrm{H}, \mathrm{td}, J 7.8$ and $1.2 \mathrm{~Hz}$, $\mathrm{H} 4), 4.60(1 \mathrm{H}, \mathrm{dd}, J 6.0$ and $1.2 \mathrm{~Hz}, \mathrm{H} 3), 4.67(1 \mathrm{H}, \mathrm{d}, J 6.0$ $\mathrm{Hz}, \mathrm{H} 2), 5.02(1 \mathrm{H}, \mathrm{s}, \mathrm{H} 1), 6.54$ (1H, d, J1,5 Hz, H5'), 7.25 $(1 \mathrm{H}, \mathrm{d}, J 2.1 \mathrm{~Hz}, \mathrm{H} 2$ '), $9.74(1 \mathrm{H}, \mathrm{d}, J 0.9 \mathrm{~Hz}, \mathrm{CHO}),(\mathrm{OH}$ signal was not observed); ${ }^{13} \mathrm{C}$ NMR $\left(75 \mathrm{MHz}, \mathrm{CDCl}_{3}\right) \delta$ 21.2 (C3”), 24.8 (C7), 26.2 (C8), 33.6 (C2”), 53.0 (C5), $55.4\left(\mathrm{OCH}_{3}\right), 61.2(\mathrm{C} 1$ ”), 81.7 (C3), 85.7 (C4), $84.8(\mathrm{C} 2)$, 109.8 (C1), 121.5 (C5'), 112.8 (C6), 124.6 (C4'), 125.2 (C3'), 131.5 (C2'), 185.8 (ㄷHO); LREIMS $m / z$ (relative abundance \%) $339\left(\mathrm{M}^{+*}, 80\right), 324$ (33), 295 (23), 277 (27), 59 (100); HREIMS Found: 339.1682. Calcd for $\mathrm{C}_{17} \mathrm{H}_{25} \mathrm{NO}_{6}$ $(\mathrm{M})^{+\bullet}: 339.1682$.

Methyl 5-deoxy-5-C-(3'-formyl-pyrrol-1'-yl)-2,3-Oisopropylidene- $\beta$-D-ribofuranoside (18)

The reaction of 3 (196 $\mathrm{mg}, 2.00 \mathrm{mmol})$, amine-riboside $9(112 \mathrm{mg}, 0.60 \mathrm{mmol})$ and $n$-butyl vinyl ether led to $\mathbf{1 8}$ (114 mg, $73 \%$ ) as an oil; IR $v_{\max } / \mathrm{cm}^{-1} 1660(\mathrm{C}=\mathrm{O}$, aldehyde) (neat); ${ }^{1} \mathrm{H}$ NMR (300 MHz, $\left.\mathrm{CDCl}_{3}\right) \delta 1.32(3 \mathrm{H}, \mathrm{s}, \mathrm{H} 7), 1.47$ $(3 \mathrm{H}, \mathrm{s}, \mathrm{H} 8), 3.40\left(3 \mathrm{H}, \mathrm{s}, \mathrm{OCH}_{3}\right), 4.05(2 \mathrm{H}, \mathrm{dd}, J 7.5$ and 1.8 $\mathrm{Hz}, \mathrm{H} 5), 4.48(1 \mathrm{H}, \mathrm{td}, J 6.0$ and $1.2 \mathrm{~Hz}, \mathrm{H} 4), 4.61(1 \mathrm{H}, \mathrm{dd}, J$ 6.0 and $1.2 \mathrm{~Hz}, \mathrm{H} 3), 4.67(1 \mathrm{H}, \mathrm{d}, J 6.0 \mathrm{~Hz}, \mathrm{H} 2), 5.08(1 \mathrm{H}, \mathrm{s}$, H1), $6.66(1 \mathrm{H}, \mathrm{q}, J 1.8$ and $1.2 \mathrm{~Hz}, \mathrm{H} 5$ '), $6.73(1 \mathrm{H}, \mathrm{t}, J 2.4$

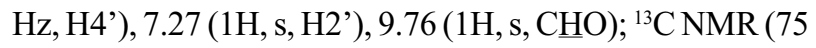
$\left.\mathrm{MHz}, \mathrm{CDCl}_{3}\right) \delta 24.8(\mathrm{C} 7), 26.4(\mathrm{C} 8), 53.1(\mathrm{C} 5), 55.5\left(\mathrm{OCH}_{3}\right)$, 81.7 (C3), 85.8 (C4), 84.9 (C2), 108.7 (C1), 109.8 (C5'), 112.8 (C6), 123.3 (C4'), 126.8 (C3'), 128.8 (C2'), 185.2 $\left(\underline{\mathrm{CHO}}\right.$ ); LREIMS $\mathrm{m} / \mathrm{z}$ (relative abundance \%) $281\left(\mathrm{M}^{+*}\right.$, 80), 266 (13), 252 (10), 68 (100); HREIMS Found: 281.1262. Calcd for $\mathrm{C}_{14} \mathrm{H}_{19} \mathrm{NO}_{5}(\mathrm{M})^{+\bullet}: 281.1261$.

\section{Results and Discussion}

The syntheses of the pyrrole compounds were carried out in two steps. The first one involved the preparation of 3carbonyldihydrofuran derivatives 4-8, which were obtained from the reaction of diazo carbonyl compounds 1-3 with 
enol ethers under dirhodium tetraacetate catalysis, as outlined in Scheme 1. The diazo compounds reacted easily with $n$-butyl vinyl ether to produce the dihydrofurans 4,5 and $\mathbf{6}$ as previously reported. ${ }^{21}$ All attempts to perform the reaction between $\mathbf{1}$ or $\mathbf{2}$ and cyclic enol ethers were unsuccessful. The same reactions with diazomalonaldehyde (3) produced the dihydrofuran derivatives $\mathbf{7}$ and $\mathbf{8}$, which were difficult to isolate. It is important to note that some of these dihidrofurans have been used in many syntheses of furanoid terpenes, ${ }^{22}$ and more recently by us in the synthesis of substituted N-alkylpyrroles. ${ }^{21}$

The nucleophilic attack of methyl 5-amino-5-deoxy$2,3-O$-isopropylidene- $\beta$-D-ribofuranoside ${ }^{23}$ (9) on the dihydrofurans $\mathbf{4}$ and $\mathbf{5}$ was performed under two different conditions: a) acetic acid, methanol, $80{ }^{\circ} \mathrm{C}$; b) acetic acid, isopropanol/water $(2: 1), 100{ }^{\circ} \mathrm{C}$. It is expected a slightly different reactivity between $\mathbf{4}$ and $\mathbf{5}$ since the former reaction involves a nucleophilic attack to vinylogous carbonyls of 3-carbonyl-dihydrofurans. In fact, in this reaction, dihydrofuran 4 proved to be more reactive than the dihydrofuran $\mathbf{5}$ since the former reacted at less drastic conditions. Usual work up and purification of the crude products by chromatography column led to the nucleosides $\mathbf{1 0}$ and $\mathbf{1 1}$ in moderate yields. Their structures were confirmed mainly based on their ${ }^{13} \mathrm{C}$ and ${ }^{1} \mathrm{H}$ NMR spectra. Selective deprotection of 2' and 3' hydroxyl groups of the later compounds, in refluxing iodine/methanol, produced the crystalline ribonucleoside derivatives $\mathbf{1 2}$ and $\mathbf{1 3}$ in $70 \%$ and $66 \%$ yield, respectively.

Diazomalonaldehyde (3) was easily decomposed with dirhodium tetracetate catalyst in the presence of $n$-butyl vinyl ether or the cyclic enol ethers to produce the dihydrofurans 6, 7 and 8 (Scheme 3) which are very sensitive to acid and partially decompose during work up in the process of removing $\mathrm{Rh}_{2}(\mathrm{OAc})_{4}$ by filtration through silica gel column. On the other hand, with the use of a Florisil ${ }^{\circledR}$ column in this procedure it was possible to isolate 7 as a sufficiently pure compound for spectroscopic purpose. We suppose this dihydrofuran is more stable than $\mathbf{6}$ and $\mathbf{8}$ due to the methyl group of the ring junction.

In order to circumvent the instability problem of the dihydrofurans 6,7 and 8 , the reaction of these compounds with benzylamine without their previous purification was investigated next.

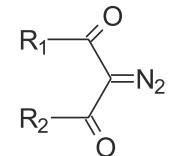

$1, \mathrm{R}_{1}=\mathrm{R}_{2}=\mathrm{CH}_{3}$

2, $\mathrm{R}_{1}=\mathrm{OEt}, \mathrm{R}_{2}=\mathrm{CH}_{3}$

3, $\mathrm{R}_{1}=\mathrm{R}_{2}=\mathrm{H}$

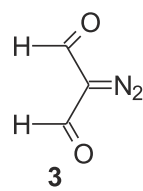

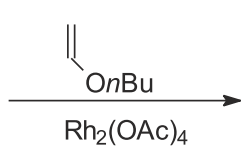

$\mathrm{CH}_{2} \mathrm{Cl}_{2}$

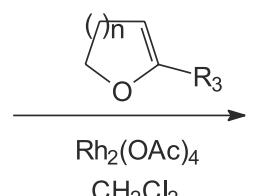<smiles>[R]C(=O)C1=C([R])OC(OCCC)C1</smiles>

4, $\mathrm{R}_{1}=\mathrm{R}_{2}=\mathrm{CH}_{3}$

5, $\mathrm{R}_{1}=\mathrm{OEt}, \mathrm{R}_{2}=\mathrm{CH}_{3}$

6, $R_{1}=R_{2}=H$

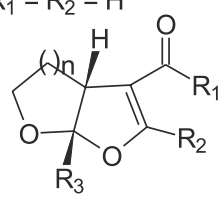

7, $\mathrm{n}=1, \mathrm{R}_{1}=\mathrm{R}_{2}=\mathrm{H}, \mathrm{R}_{3}=\mathrm{CH}_{3}$

8, $n=2, R_{1}=R_{2}=R_{3}=H$

Scheme 1. Syntheses of dihidrofurans 4-8 from diazo carbonyl compounds 1-3

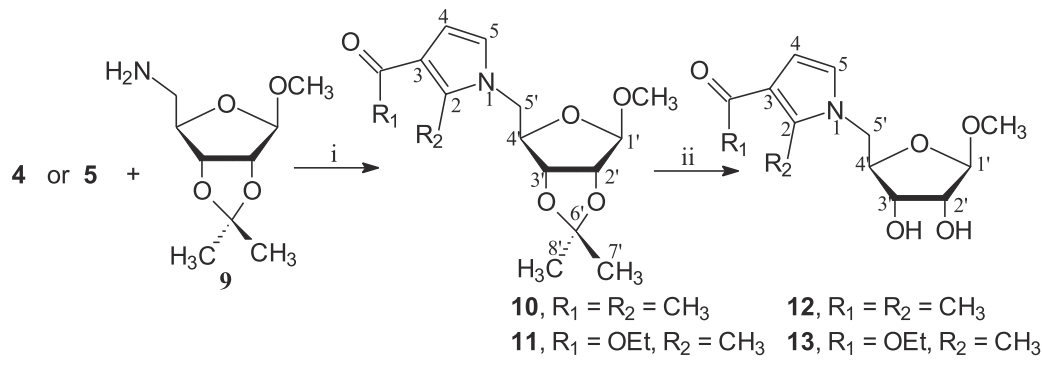

(i) $\mathrm{CH}_{3} \mathrm{CO}_{2} \mathrm{H} / \mathrm{CH}_{3} \mathrm{OH}, 80{ }^{\circ} \mathrm{C}, 24 \mathrm{~h}$ or $\mathrm{CH}_{3} \mathrm{CO}_{2} \mathrm{H} / i-\mathrm{PrOH} / \mathrm{H}_{2} \mathrm{O}(2: 1), 100{ }^{\circ} \mathrm{C}, 24 \mathrm{~h}$

(ii) $\mathrm{I}_{2} / \mathrm{CH}_{3} \mathrm{OH}, 80{ }^{\circ} \mathrm{C}, 10 \mathrm{~h}$ 


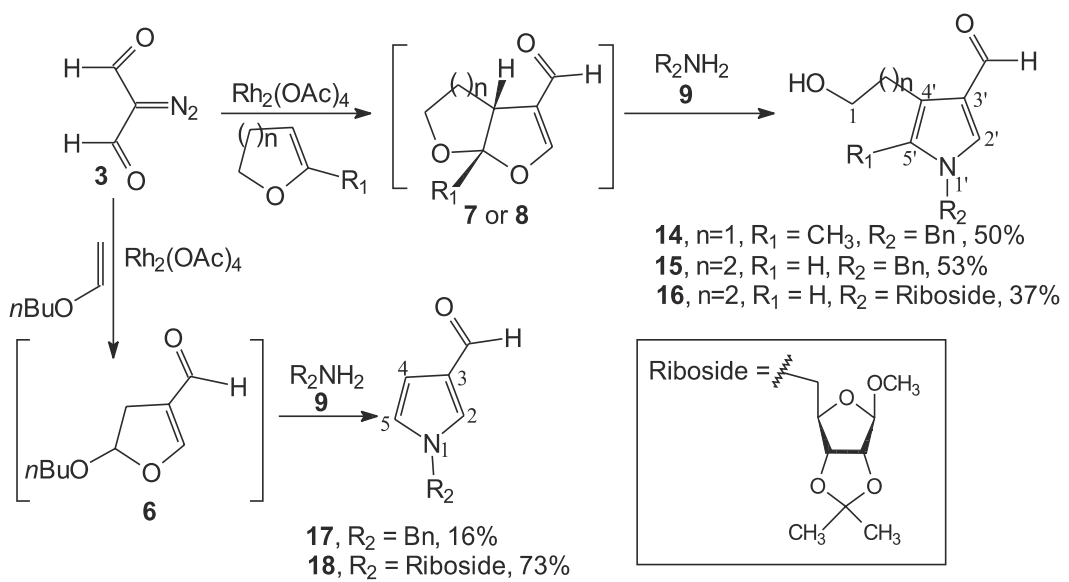

Scheme 3. Preparation of pyrrole derivatives 14-18 from diazomalonaldehyde (3)

The reaction of diazomalonaldehyde (3) with $n$-butyl vinyl ether, dihydropyran or methyl-dihydrofuran, in the presence of catalytic amount of dirhodium tetraacetate, produced the crude mixtures of the 3-carbonyldihydrofurans 6,7 and 8 . After removal of the rhodium catalyst by filtration through a Florisi ${ }^{\circledast}$ pad eluted with hexane/chloroform $50 \%$, the organic mixture was concentrated under vacuum and the reaction with benzylamine was performed in methanol/acetic acid yielding the corresponding pyrroles 14,15 and 17 in 50\%, $53 \%$ and $16 \%$ yields, respectively (Scheme 3 ).

Having succeeded in these reactions, dihydrofurans 6 and $\mathbf{8}$ were reacted with the aminoribofuranoside $\mathbf{9}$, using this previously established general procedure. This led to the desired pyrrole ribonucleoside derivatives 18 (73\%) and $16(37 \%)$, respectively (Scheme 3$)$. The lower yield in the synthesis of $\mathbf{1 6}$ is probably related to the lower stability of the dihydrofuran intermediate $\mathbf{8}$ in the acidic condition. The structures of these pyrrole derivatives were assigned mainly based on their ${ }^{13} \mathrm{C}$ and ${ }^{1} \mathrm{H}$ NMR spectra. The pyrroles 14, 15, 16 and 18 are new compounds in the literature, while 17 was previously synthesized by two other different routes. ${ }^{24,25}$

\section{Conclusions}

Novel methodologies concerning the preparation of pyrroles continue to be extensively studied during these years leading to new dimensions in the design of synthetic strategies for the construction of the heterocyclic ring. This work highlights the applicability of a simple methodology based on the pyrrole ring construction for the synthesis of reverse nucleoside analogues. Even though this methodology was not tested for a large number of dihydrofurans and for other amine-carbohydrates, this seems to be a good process for obtaining new reverse pyrrole nucleosides in few steps.

\section{Acknowledgments}

Fellowships granted to A. C. Cunha and L. O. R. Pereira from CNPq (Brazil) and CAPES are gratefully acknowledged, respectively. M. C. B. V. de Souza and V. F. Ferreira are grateful to CNPq for the individual research fellowships. We thank UNICAMP-IQ for MS spectra. We also thank Dr. G. A. Romeiro (UFF, Brazil) for useful advices. This work was partially supported by CNPq (National Council of Research from Brazil) and FAPERJ.

\section{References}

1. Gimenez, I. F.; Alves, O. L.; J. Braz. Chem. Soc. 1999, 10, 167.

2. D'Silva, C.; Walker, D. A.; J. Org. Chem. 1998, 63, 6715.

3. Spivey, A. C.; Frampton, C. S.; Battersby, A. R.; J. Chem. Soc. Perk. T. 1 1996, 61, 2103; Jacobi, P. A.; Buddhu, S. C.; Fry, D.; Rajeswari, S.; J. Org. Chem. 1997, 62, 2894; Leung, S. H.; Nguyen, L. T.; Smith, K. M.; Heterocycl. Commun. 1996, 2, 9; Gupton, J. T.; Krumpe, K. E.; Burnham. B. S.; Dwornik, K. A.; Tetrahedron 1998, 54, 5075; Fürstener, A.; Weintritt, H.; Hupperts, A.; J. Org. Chem. 1995, 60, 6637.

4. For recent reviews on synthesis of pyrrolizidine and indolizidine alkaloids, see: Casiraghi, G.; Zanardi, F.; Rassu, G.; Pinna, L.; Org. Prep. Proced. Int. 1996, 28, 641; Takohata, H.; Momose, T. In The Alkaloids; G. A. Cordell, ed., Academic Press: San Diego, 1993.

5. De Kimpe, N.; Tehrani, K. A.; Stevens, C.; De Cooman, P.; Tetrahedron 1997, 53, 3693.

6. Khanna, I. K.; Weier, R. M.; Yu, Y.; Collins, P. W.; Miyashiro, J. M.; Koboldt, C. M.; Veenhuizen, A. M.; Currie, J. L.; Seibert, K.; Isakson, P. C.; J. Med. Chem. 1997, 40, 1619. 
7. Thurkauf, A.; Yuan, J.; Chen, X.; Wasley, J. M.; Meade, R.; Woodruff, K. H.; Huston, K.; Ross, P. C.; J. Med. Chem. 1995, 38,4950 .

8. Ferreira, V. F.; de Souza, M. C. B. V.; Cunha, A. C.; Pereira, L. O. R.; Ferreira, M. L. G.; Org. Prep. Proced. Int. 2001, 33, 411; Lue, P.; Greenhill, J. V.; Adv. Heterocycl. Chem. 1996, 67, 207; Jones, R. A.; Chem. Heterocycl. Compd. 1990, $38,1$.

9. Sundberg, R. J. In Comprehensive Heterocyclic Chemistry II; Katritzky, A. R.; Rees, C. W.; Scriven, E. F. V., ed.; Pergamon: Oxford, v. 2, p. 119, 1996; Jones, R. A.; Been, G, P. In The Chemistry of Pyrroles; Academic Press: New York, 1977; Collins, I.; J. Chem. Soc. Perkin Trans 1 2000, 2845; Gilchrist, T. L.; J. Chem. Soc. Perkin Trans 1 1998, 615; ibid 1999, 2849.

10. Huisgen, R.; Stangl, H.; Sturm, H. J.; Wagenhofer, H.; Angew. Chem., Int. Ed. 1962, 1, 50 .

11. Kawana, M.; Emoto, S.; Bull. Chem. Soc. Jpn. 1968, 41, 2552; Kawana, M.; Emoto, S.; Bull. Chem. Soc. Jpn. 1969 , 42, 3539; Ramasamy, K.; Robins, R. K.; Revankar, G. R.; Nucleos. Nucleot. 1987, 6, 261; Ramasamy, K.; Robins, R. K.; Revankar, G. R.; J. Heterocycl. Chem. 1987, 24, 863; Maeba, I.; Takeuchi, T.; Iijima, T.; Kitaori, K.; Muramasu, K.; J. Chem. Soc. Perkin Tran 1 1989, 649.

12. Lazrek, H. B.; Taorirte, M.; Oulih, T.; Kabbaj, Y.; Barascut, J. L.; Imbach, J. L.; Almasoudi, N. A.; Pfleiderer, W.; Nucleos. Nucleot. 1997, 16, 1073; Buffel, D. K.; Meerpoel, L.; Toppet, S. M.; Hoornaert, G. J.; Nucleos. Nucleot. 1994, 13, 719; Fossey, C.; Laduree, D.; Robba, M.; Nucleos. Nucleot.1994, 13, 883; Forestier, M. A.; Ayi, A. I.; Condom, R.; Boyode, B P.; Colin, J. N.; Selway, J.; Challand, R.; Guedj, R.; Nucleos. Nucleot. 1993, 12, 915; Caputo, R.; Guaragna, A.; Palumbo, G.; Pedatella, S.; Nucleos. Nucleot. 1998, 17, 1739; Grosselin, G.; Boudou, V.; Griffon, J. F.; Pavia, G.; Pierra, C.; Imbach, J. L.; Faraj, A.; Sommadossi, J. P.; Nucleos. Nucleot. 1998, 17, 1731.

13. Girardet, J.; Drach, J. C.; Chamberlain, S. D.; Koszalka, G. W.; Townsend, L. B.; Nucleos. Nucleot. 1998, 17, 2389; Migawa, M. T.; Girardet, J.; Walker, II, J. A.; Koszalka, G. W.; Chamberlain, S. D.; Drach, J. C.; Townsend, L. B.; J. Med. Chem 1998, 41, 1242.

14. Wu, J.; Schneller, S. W.; Seley, K. L., De Clercq, E.; Heterocycles 1998, 47, 757.

15. de Souza, M. C. B. V.; Soares, M. C.; Ferreira, V. F.; Quim. Nova 2001, 24, 206; Cunha, A. C.; Pereira, L. O. R.; Souza, R. O. P.; de Souza, M. C. B. V.; Ferreira, V. F.; Nucleos. Nucleot.
\& Nucleic acid 2001, 20, 1555; Matta, A. D.; dos Santos, C. V. B.; Pereira, H. S.; Frugulhetti, I. C. de P. P.; Oliveira, M. R. P.; de Souza, M. C. B. V.; Moussatché, N.; Ferreira, V. F.; Heteroatom Chem. 1999, 10, 197; Cunha, A. C.; Pereira, L. O. R.; de Souza, M. C. B. V.; Ferreira, V. F.; J. Chem. Educ. 1999 76, 79; Bernardino, A. M.; Nogueira, C. M.; Lepesch, C. M. de O.; Gomes, C. R. B.; Schmitz, F. J.; Romeiro, G. A.; Pereira, H. S.; Frugulhetti, I. C. P. P.; de Oliveira, M. R. P.; de Souza, M. C. B. V.; Lee, M. Y. W. T.; Chaves, S. A.; Ferreira, V. F.; Heterocycl. Commun. 1997, 3, 527; Matta, A. D.; Bernardino, A M. R.; Romeiro, G. A.; de Oliveira, M. R. P.; de Souza, M. C. B. V.; Ferreira, V. F.; Nucleos. Nucleot. 1996, 15, 889.

16. For a recent review about diazocarbonyl compounds, see: Ferreira, V. F.; Cunha A. C.; Pereira, L. O. R.; de Souza, M. C. B .V.; Quim. Nova 2001, 24, 540; Doyle, M. P.; Forbes, D. C.; Chem. Rev. 1998, 98, 911; Brandi, A.; Goti, A.; Chem. Rev. 1998, 98, 589;

17. Rosenberger, M.; Yates, P.; Tetrahedron Lett. 1964, 33, 2285.

18. Doering, W. V. E.; De Puy, C. H.; J. Am. Chem. Soc. 1953, 75 , 5955

19. Arnold, Z.; Sauliová, J.; Coll. Czech. Chem. Commun. 1973, $38,264$.

20. Ferreira, V. F.; PhD Thesis, University of California San Diego, USA, 1984; Wenkert, E.; Hoffmann, M. G.; Tetrahedron 1993, 49, 1057; Foley, L.; Tetrahedron Lett. 1994, 35, 5989; Alonso, M. E.; Morales, A.; Chitty, A. W.; J. Org. Chem. 1982, 47, 3747; Davies, H. M. L.; Ahmed, G.; Calvo, R. L.; Churchill, M. R.; Churchill, D. G.; J. Org. Chem. 1998, 63, 2641.

21. Cunha, A. C.; Ferreira, V. F.; de Souza, M. C. B.V.; Pereira, L. O. R.; Synth. Commun. 2000, 40, 3215.

22. Wenkert, E.; Ferreira, V. F.; Ananthanarayan, T. P.; Khim, H.; Hoffmann, M. G.; J. Org. Chem. 1990, 55, 4975; Wenkert, E.; Alonso, M. E.; Buckwalter, B. L.; Chou, K. J.; J. Am. Chem Soc. 1977, 99, 4778; Alonso, M. E.; Jano, P.; Hernandez, M. I.; Greenberg, R. S.; Wenkert, E.; J. Org. Chem. 1983, 48, 3047; Wenkert, E.; Acc. Chem. Res. 1980, 13, 27; Wenkert, E.; Heterocycles 1980, 14, 1703.

23. Secrist III, J. A.; Logue, M. W.; J. Org. Chem. 1972, 37, 335.

24. Ducrocq, C.; Bisagni, E.; Lhoste, J. M.; Mispelter, J.; Tetrahedron 1976, 32, 773

25. Downie, I. M.; Earle, M. J.; Heaney, H.; Shuhaibar, K. F.; Tetrahedron 1993, 49, 4015 .

Received: March 23, 2001

Published on the web: May 6, 2002 